\title{
From Patronage to Policy: The Centralization Campaign and Iowa Post Offices, 1890-1915
}

\author{
DANIEL P. CARPENTER
}

RURAL LIFE at the dawn of the twentieth century seemed far removed from the workings of the national government, and in the main it was. Alexis De Tocqueville remarked that American government had "no administrative officers of its own, stationed at fixed points in its territory to whom it can give a common impulse. ${ }^{11}$ While national politics had a dramatic impact on states such as Iowa in the nineteenth century, national administration left little mark. Aside from the U.S. Department of Agriculture's engagement with experimentation at Iowa Agricultural College,

1. Alexis DeTocqueville, Democracy in America, trans. George Lawrence, ed. J. P. Mayer (Garden City, NY, 1969), part I, chap. 5, p. 90. Tocqueville's characterization of antebellum America has been much criticized, particularly on its lack of attention to early postal institutions, which were far more dispersed throughout the territory in the United States than in France. See Richard John, Spreading the News: The American Postal System from Franklin to Morse (Cambridge, MA, 1995); and Theda Skocpol, "The Tocqueville Problem: Civic Engagement in American Democracy," Social Science History 21 (1997), 455-79.

I thank the State Historical Society of Iowa for research support and archival assistance, and the National Archives for assistance. I also acknowledge Samuel Kernell, Michael McDonald, the editor, and four anonymous reviewers for helpful criticisms that improved the argument. Elements of this research were presented at the 1998 annual meetings of the American Political Science Association (Boston, MA), the Seminar on Political Institutions at the University of Michigan, the American Politics Workshop at Princeton University, and the Organizations and State-Building Workshop of the University of Chicago. I assume sole responsibility for all interpretations and errors herein.

THE ANNALS OF IOWA 58 (Summer 1999). CThe State Historical Society of Iowa, 1999. 
and the operations of the General Land Office of the Interior Department (which by the close of the century had waned considerably), the involvement of officers of the federal government with Iowans was rare and fleeting. By the end of the century, moreover, this involvement was declining. The expansion of national government during Reconstruction was decades past, the Agriculture Department's scientific work diminished during the 1890s, and the one agency most intimately involved with the West, the Interior Department, had shifted most of its operations farther westward. As Stephen Skowronek has argued, the national "state" in late nineteenth-century America consisted not in bureaucracy, but in a network of courts and the hegemony of parties. ${ }^{2}$

The national postal system was the clear exception to this state of affairs. Before 1900, no other federal government agency was so intricately and materially involved in rural locales as the Post Office Department. As Richard John has eloquently and painstakingly narrated in Spreading the News, the Post Office was the source of profound cultural and political transformations in the 1800 s. Many characteristic elements of nineteenthcentury politics and culture-the cementing of a national market for information, the patronage system, the nationalization of political issues-are simply inconceivable in the absence of a far-flung postal system the likes of which no other nation had. ${ }^{3}$

Even in postal operations, however, the law of localism reigned supreme. The late nineteenth-century Post Office Department, while impressive as a network of mail delivery, was little integrated or centralized as an administrative organization. ${ }^{4}$ Some of the reasons for this state of affairs are now well known among historians. The most compelling is party patronage. The "spoils" system that characterized national government from

2. R. K. Bliss, A History of Cooperative Agriculture and Home Economics Extension in Iowa (Ames, 1960); Stephen Skowronek, Building a New American State: The Expansion of National Administrative Capacities (New York, 1981).

3. John, Spreading the News.

4. The Railway Mail Service marked an exception to this lack of integration. Yet until the RMS was integrated with the postal inspection corps, the integration and efficiency of the RMS did not materially affect the rest of the department's operations. See below. 
1830 onwards decimated the relative efficiencies of Federalist and Jeffersonian postal policy, and it left the tinge of corruption and inefficiency upon the federal bureaucracy, to say nothing of numerous state and local governments also affected by it. In rural locales postal patronage took a unique form. The dominant patronage figure of rural life was not the machine boss but the general-store postmaster. The fourth-class postmaster, as Wayne Fuller describes, was a virtual institution. The office was often run out of the postmaster's store, and the resulting traffic in persons gave the postmaster economic security and centrality in the rural community. Few individuals were more important to the career of a congressional representative. The result was local autonomy: fourth-class postmasters had security (and much leeway) in their jobs as long as their party was in power. ${ }^{5}$

Beginning in the 1890s, the old regime of postal operations gradually gave way to a "new regime" as postal executives in Washington took increasing control of local operations. The emergence of this new regime was driven in part by the "efficiency" rhetoric of Progressivism, in part by new programs favored by congressional agrarians, but even more by the organizational control imperatives of the Post Office Department. Where local autonomy reigned before the 1890 s, postal inspectors thereafter began to intrude into every aspect of local operations. Where postal spending and accounting were highly decentralized before 1900, the department stepped in to rein in costs and standardize accounts. This transformation is particularly evident in Iowa. One of the strongest states in the postReconstruction Republican stronghold, Iowa was home to the quintessence of the patronage system: numerous small-scale post offices of the first, second, and third classes, with firmly entrenched incumbent postmasters, as well hundreds of fourthclass post offices dotting the countryside. Iowa also stands as a chief example of the department's reform efforts. After 1890, few states made the transition from patronage to policy as quickly.

Another legacy of postal change- one centrally tied to the culture of rationalization-was the eclipse of women's manage-

5. Wayne Fuller, RFD: The Changing Face of Rural America (Bloomington, IN, 1964). 
rial roles. A forgotten aspect of patronage is that it saw women in numerous positions of workplace authority and discretion, sometimes in the position of postmaster itself. As postal centralization gained ground, women were increasingly relegated to clerical work. The consequences of postal reform provide a vivid example of the "clericalization" of women's work in the Progressive Era. ${ }^{6}$

THE YEAR 1883 was a banner year in government administration. Congress passed the Pendleton Act, a measure that legally buried the spoils system. ${ }^{7}$ Yet that same year the Post Office witnessed its last operations surplus for three decades. In 1883 the post office accounts stood over $\$ 2$ million in the black. A year later they were almost $\$ 4$ million in the red, or 9 percent of revenues. In 1885 the deficit ballooned to $\$ 7.4$ million, or 17 cents on every dollar of revenues. While congressional policy often encouraged fiscal profligacy with numerous expansions of free delivery service, the deficits of the 1880s and 1890s brought ringing criticism upon the department for its surfeit of offices, its inefficient workers, and its dated methods. For the Gilded Age Post Office, the legacy of patronage was a reputation for sloth. ${ }^{8}$

In the 1890s, more than at any time since John McLean's term as Postmaster General in the 1820s, Post Office officials cared deeply about the reputation of their agency. After 1860 a new reform-minded cadre of postal officials arose, chiefly from

6. Margary Davis, A Woman's Place Is at the Typewriter: Office and Office Workers, 1870-1930 (Philadelphia, 1982); Elyce J. Rotella, From Home to Office: U.S. Women at Work, 1870-1930 (Ann Arbor, MI, 1981); Carole Srole, "A Position That God Has Not Particularly Assigned to Men: The Feminization of Clerical Work, Boston, 1860-1915" (Ph.D. diss., University of California, Los Angeles, 1984); Angel Kwolek-Folland, Engendering Business: Men and Women in the Corporate Office, 1870-1930 (Baltimore, 1994).

7. The burial of spoils in practice would come incrementally by the decisions of successive presidents to "cover in" certain departments and classes of workers under the Pendleton law.

8. See Postmaster General, Annual Reports, 1890-1912. For a more thorough review of the department's weak reputation during this period, see Daniel $P$. Carpenter, "The Waning of the Old Postal Regime, 1862-1894," book chapter manuscript, University of Michigan. 
the ranks of the department's cohesive and insular Railway Mail Service. These reformers aimed to expand the department's role in American political economy, by moving into new areas of communication and transportation, by reshaping the Post Office Department into a machine-like enterprise, even by using the department's powers to regulate American sexuality. The new regime included postal inspector Anthony Comstock, attorney James Tyner, railway superintendent James White, reformer August Machen and Postmaster General John Wanamaker. The reform wing was ideologically cohesive, Republican (yet distrustful of the party's old guard), and bent upon the obliteration of the old Jacksonian way of doing things.

The primary strategy of the reformers was to increase the presence of inspectors in everyday operations. Comstockerythe late nineteenth-century anti-pornography movement centered in the post office and civic "vice suppression societies" fueled the increase of inspectors, but postal executives detailed most of them not to "anti-adulteration" work, but to the monitoring of local offices. The national inspection force had been stagnant for most of the century, even with the proliferation of offices and mail routes, yet quintupled from just over 20 during Reconstruction to 100 by 1897 . From 1897 to 1910 the inspection force tripled, reaching more than 300 inspectors by Taft's inauguration. Crucially, the postal inspection force and the chief inspector were placed not under the assistant postmasters general, but under the postmaster general himself. Still, the inspectors took guidance from the first and second assistant postmasters general (in charge of city delivery and transportation policy, respectively). Under guidance from postal executives such as First Assistants Perry S. Heath and Frank Hitchcock,

9. On the evolution of the Railway Mail Service, see Daniel P. Carpenter, "The Corporate Metaphor and Executive Department Centralization in the United States, 1880-1920," Studies in American Political Development 12 (1998), 162-203. On the emergence of a reform wing in the Post Office Department, see idem, "State-Building through Organizational Renewal: Reputation and Program Expansion in National Postal Administration, 1883-1913," paper presented at the annual meeting of the American Political Science Association, 1998. The most thorough portrait of the department in the 1890s appears in Marshall Cushing, The Story of Our Post Office: The Greatest Government Department in All Its Phases (Boston, 1893). 
Second Assistants J. Louis Ball and G. F. Stone and others, inspectors delved into the "reliability" and "regularity" of all manner of local operations, including postmasters' accounts, their quarterly reports, contract bidding, and star route service. ${ }^{10}$

The impetus for reform (and for lowering the deficit) crested in the early 1890s, when Postmaster General John Wanamaker proposed an ambitious new set of policies, including government operation of the telegraph, a parcel post, a rural free delivery system, and seven other wide-ranging reforms. Yet with the postal deficit at over 10 percent of revenues, Congress balked. Members of Congress and the press cited the department's deficit as an obstacle to any expansion of the postal mandate. ${ }^{11}$ Throughout this period, postal reformers understood that improving the department's fiscal balance was a necessary condition for the satisfaction of their designs.

10. Wayne Fuller, The American Mail (Chicago, 1972), 273-77; Cushing, The Story of Our Post Office, 617. For a thorough archive of the guidance given to special agents by Washington officials, see Office of the Second Assistant Postmaster General, "Letters Sent To Special Agents, 1894-1904," National Archives (hereafter NA), Record Group (RG) 28 (Records of the Post Office Department), Entry (E) 102. On "reliability" in contract bidding, see W. S. Shallenberger [Second Assistant Postmaster General] to Irvin W. Mayfield, 10 January 1903, NA, RG 28, E 102, box 1, vol. 1, p. 6. On "reliability" in postmasters' reports, see Shallenberger to W. C. Heckman, asst. supt. RMS, 9 February 1903, ibid., p. 90.

11. When Wanamaker floated the rural free delivery idea in the early 1890 s, many newspapers doubted the very possibility of a fiscally balanced postal program. Admitted the otherwise enthusiastic editor of the Steubenville (Ohio) Star, "the Government Post-Office, it is true, is far from being self-sustaining." For editorial concern about the postal deficit, see Wanamaker's voluminous report, "Free Delivery System," 3 May 1892, Senate Exec. Doc. No. 92, 52d Cong., 1st sess., 173 (also 123). Even 15 years later when the department had reduced the deficit to 5 percent of revenues, opponents of its favored program - parcel post delivery-still pressed deficit concerns. The Chicago Dry-Goods Reporter warned of "the enormous annual deficit which the parcels business cannot fail to create in the postal department." Chicago Dry-Goods Reporter, 26 February and 3 March 1900. Charles William Burrows, the most eloquent of parcel post's detractors, pointed to program losses in the special delivery service, money orders, and early rural delivery and claimed that "the service is blow-holed, full of inaccuracy and fraud upon which there is no efficient check." Charles William Burrows "Thoughts Upon Some Proposed Parcels Post Legislation," an address delivered at the Union Club, Cleveland, 30 October 1906, pp. 1, 12, Firestone Library, Princeton University. See also the petitions of Hills, Minnesota, and Pana, Illinois, in House Committee Files, "Parcel Post," NAI, RG 233, HR56A-H21.9. 
FIGURE 1

The Advance of Postal Inspection in Iowa, 1898-1909

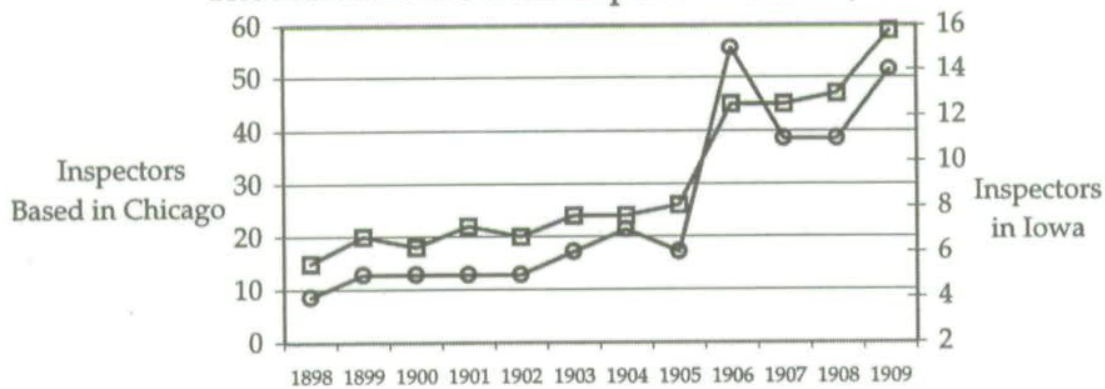

- Inspectors based in Chicago - Inspectors detailed to Iowa

Iowa also witnessed a burgeoning and more aggressive force of postal inspectors. Inspectors for the Iowa post offices were based in headquarters in Chicago, managed from 1889 onwards by Chief Inspector James E. Stuart. Stuart had four decades of experience in the department and had served in the Railway Mail Service with its founder, George Armstrong. From 1898 to 1909 the number of inspectors based in Chicago quadrupled, from 15 to 59 . Whereas only four inspectors were explicitly detailed to Iowa operations in 1898, by 190914 individuals monitored Iowa operations, and many more regulated Rural Free Delivery (see fig. 1). Most of Iowa's inspectors, unlike those in most other states, were highly experienced. Besides James Stuart's three decades of service, C. E. Stewart headed the Iowa force throughout the expansion period. Stewart took over in 1898 and remained at least until 1911, when available personnel rosters end. ${ }^{12}$

12. A discussion of rural free delivery appears below. None of the inspectors in the statistical samples here were rural special agents (who inspected rural free delivery service). Rural agents were not joined with the regular postal inspection force until December 1905, and even then they were kept separate from the other agents. See "Order of the Postmaster General" [George Cortelyou], Order No. 448, 1 November 1905, copy in Haugen Papers, box 93, booklet marked "Post Office \#1," State Historical Society of Iowa, Iowa City. On Stuart's experience under Armstrong, see "Recollections of M. J. McGrath, Superintendent of Free Delivery, Chicago Post Office," in George Armstrong Collection, Chicago Historical Society. Armstrong's claim to have originated the service was later challenged in William A. Davis, The Railway Postal Service: Originated by William A. Davis of St. Joseph, Missouri (Washington, DC, 1888). 
Iowa inspectors stood out in one other respect. A high proportion of the Iowa inspectors was drawn from the ranks of the Railway Mail Service (RMS), the organizational base of the postal reform wing. Its members detested the inefficiency, congressional favor, and facile work that, in their view, characterized most postmasters. As a result, postal inspectors trained in the Railway Mail Service aggressively pursued malfeasance in local offices. In 1898, 47 percent of Chicago-based inspectors, including C. E. Stewart, the leader of the Iowa force, had been hired directly from the RMS. ${ }^{13}$

At the turn of the century, then, names such as C. E. Stewart, Harry Hadsel, James T. Boylan, Alex Charles, John Mahin, and others were an ever more common presence in Iowa post offices. Moreover, through the inspectors' actions, the presence of executives in Washington and Chicago such as Frank Hitchcock, J. Louis Ball, G. F. Stone, and James Stuart was also enhanced. The days of administrative solitude were over.

THE NEW REGIME had the effect of relentlessly standardizing numerous aspects of postal operations in Iowa and elsewhere. In the 1870 s and 1880 s, accounts in most offices were written in whatever form the postmaster wished to record them even though formal account books existed for their use. In the 1880 s, money order books for George M. Howlett, postmaster of the Cedar Rapids office, contained a summary page for each business day, whereas the books for Postmaster J. T. Urice of Garrison (a fourth-class office) included a separate entry for each individual order. The only common feature of both offices'

13. On the organizational ideology of the RMS, see Carpenter, "The Corporate Metaphor and Executive Department Centralization"; and idem, "State Building through Organizational Renewal." Inspectors' information drawn from National Archives inspectors rosters, "Rosters 1898-1909," which contain personnel information to 1911, NA, RG 28, E 234. The fraction of inspectors who spent at least part of their previous careers in the RMS (including those who were not hired directly from the service) is higher, but unavailable in existing records. Because the National Archives data code only the service from which the inspector was hired, they exclude inspectors who were trained in the RMS yet who also worked for another division of the department before being hired into the inspectors' corps. Hence the reported fractions are a lower limit on the percentage of inspectors who were trained in the RMS. 
records is the loose scribble in which they were kept, many entries being illegible to any eyes but the postmaster's. Such disparities across offices were a primary target of the inspectors, as is evident from a remark made in the early 1890 s by Marshall Cushing, secretary to Postmaster General John Wanamaker: "The great bulk of an inspector's work consists of investigations of simple irregularities in the mail service. The fourth class postmasters do not carefully observe the rules and regulations, and hence much carelessness, where there is no dishonesty, results. ${ }^{14}$

After the department issued a new set of regulations in 1893, however, uniform accounting procedures quickly took hold in the nation's post offices. Postmasters no longer jotted down receipts according to their discretion or personal organizational style. Instead, they completed the standard account forms that Washington had been issuing for years. Cash books and account books from Cedar Rapids and Garrison in the late 1890s and early 1900 s appear utterly unlike those of the 1880 s. The department also targeted postmarking. Accurate postmarking was essential for inspectors who sought stolen mail or fraudulent businesses. In 1897 First Assistant Postmaster Perry Heath issued a circular that standardized the practice. Heath's circular warned that the Post Office was "determined to secure a radical reform in the method of postmarking," demonstrating the reformers' commitment to overhauling the most minute operations. ${ }^{15}$

In first- and second-class offices-those in larger cities and towns such as Cedar Rapids, Iowa City, and Oskaloosa-many other practices and activities were standardized. Among the

14. Cash Book, George M. Howlett, Postmaster, Cedar Rapids, 1870 and 1881, Records of the Cedar Rapids Post Office, State Historical Society of Iowa, Iowa City (hereafter SHSI); Cash Book, 1887-1888, J. T. Urice, Postmaster, Garrison, Records of the Garrison Post Office, SHSI; Cushing, The Story of Our Post Office, 313. Formal account books existed from the 1830 s and were widely used for reporting to Washington, but supplemental account books kept at local post offices varied more widely in use. I thank an anonymous reviewer for clarifying this point.

15. For standardized forms, see Accounts and Records, Cedar Rapids Post Office, 1898-1900; Account and Record Book, Cedar Rapids Post Office, 1916; and Cash Book, Cedar Rapids Post Office, 1916-17, in Records of the Cedar Rapids Post Office, SHSI; Perry Heath, "Official Instructions in Relation to Postmarking and Backstamping," Washington, D.C., 14 May 1897, ibid.; Cushing, The Story of Our Post Office, $432 \mathrm{ff}$. 
most important concerned residential and business deliveries under the free delivery service. In the early 1890s Iowa post offices varied widely in the frequency of their delivery patterns. Council Bluffs offered two residential deliveries per day in 1896, while Muscatine and Fort Madison offered one, Iowa City four, and Oskaloosa five. These patterns were not directly related to the cities' size or business activity, for Davenport and Dubuque, each several times larger than Oskaloosa, had two residential deliveries per day to Oskaloosa's five. A similarly wide variance accompanied the cities' business delivery practices, where the frequency of carriage in 1897 ranged from five per day in Iowa City to twice in Muscatine. By 1910, this scattered state of individual office operations had largely disappeared. Most of Iowa's first- and second-class offices operated much as Cedar Rapids, where Postmaster W. G. Haskell described his daily operations in 1911 as follows:

Cedar Rapids has thirty incoming and thirty-eight outgoing mails daily. Four deliveries of mail in the business districts and two in the residence districts are made daily (except Sunday); one delivery each day (except Sunday) over all rural routes. Four daily foot collections and two mounted collections are made in the business districts and two in the residence districts (except Sunday). ${ }^{16}$

By the time of Haskell's report, Iowa's larger post offices had converged to near uniformity in the frequency of deliveries (see table 1). Whereas just over half of Iowa post offices delivered to businesses three or four times daily in 1896, fully 86 percent of offices made three or four daily deliveries by 1910 . The standardization was even more pronounced in residential deliveries. Whereas four in ten offices delivered twice per day to residences in 1896, every one of Iowa's 36 first- and secondclass offices settled on two daily residential deliveries by $1910 .{ }^{17}$

As in delivery patterns, so with uniforms. Although uniforms had been worn in eastern cities since the 1860s, their use was not standardized, and they were rarely seen in western and

16. "United States Post Office, Cedar Rapids, Iowa, with Compliments of W. G. Haskell, Postmaster" (1911), p. 7, Records of Cedar Rapids Post Office.

17. See Post Office Department survey of first- and second-class offices, 18961910, NA I, RG 28, E 95. 
TABLE 1

THE STANDARDIZATION OF DELIVERY PATTERNS FOR FIRST- AND SECOND-CLASS POST OFFICES IN IOWA, 1896-1910

\begin{tabular}{ccccc}
\hline Year & $\begin{array}{c}\text { Percentage of } \\
\text { offices with } \\
\text { TWO } \\
\text { daily residential } \\
\text { deliveries }\end{array}$ & $\begin{array}{c}\text { Percentage of } \\
\text { offices with } \\
\text { THREE } \\
\text { daily business } \\
\text { deliveries }\end{array}$ & $\begin{array}{c}\text { Percentage of } \\
\text { offices with } \\
\text { FOUR } \\
\text { daily business } \\
\text { deliveries }\end{array}$ & $\begin{array}{c}\text { Percentage of } \\
\text { offices with } \\
\text { THREE or FOUR } \\
\text { daily business } \\
\text { deliveries }\end{array}$ \\
\hline 1896 & 42 & 25 & 29 & 54 \\
1897 & 50 & 29 & 38 & 67 \\
1898 & 79 & 57 & 21 & 79 \\
1899 & 83 & 45 & 34 & 79 \\
1900 & 87 & 40 & 43 & 83 \\
1901 & 88 & 44 & 28 & 72 \\
1902 & 85 & 39 & 27 & 67 \\
1903 & 86 & 35 & 31 & 66 \\
1904 & 86 & 38 & 33 & 72 \\
1905 & 86 & 44 & 31 & 75 \\
1906 & 89 & 44 & 31 & 78 \\
1907 & 89 & 44 & 33 & 81 \\
1908 & 92 & 53 & 28 & 83 \\
1909 & 92 & 53 & 31 & 86 \\
1910 & 100 & 50 & 36 & \\
\hline
\end{tabular}

SOURCE: Sample of 36 first- and second-class post offices in Iowa, from National Archives survey, Record Group 28, Entry 95.

southern towns. The department promulgated regulations in 1894 encouraging carriers to wear uniforms. Carriers lamented their "heavy blue helmets" during humid summers. In Cedar Rapids, the office adopted a gray uniform with wide-brimmed hats and dark neckties, prompting a local newspaper to joke that the carriers looked "just a little like confederate generals fresh from the battlefield at Gettysburg." The helmets gave way to lighter hats, but the uniforms remained. ${ }^{18}$

18. See the recollections of New Orleans mail carrier Ozenine Kinler in "Oldest Postman Still Spry After 41 Years' Service," Times-Picayune, 15 November 1925, Louisiana Collection, Howard-Tilton Memorial Library, Tulane University. A 1907 portrait of letter carriers in their new uniforms appears in the Cedar Rapids Gazette, 5 April 1959 (see ill.). See also Postmaster W. G. Haskell, United States Post Office, Cedar Rapids, Iowa. Both in Cedar Rapids Post Office Files. 


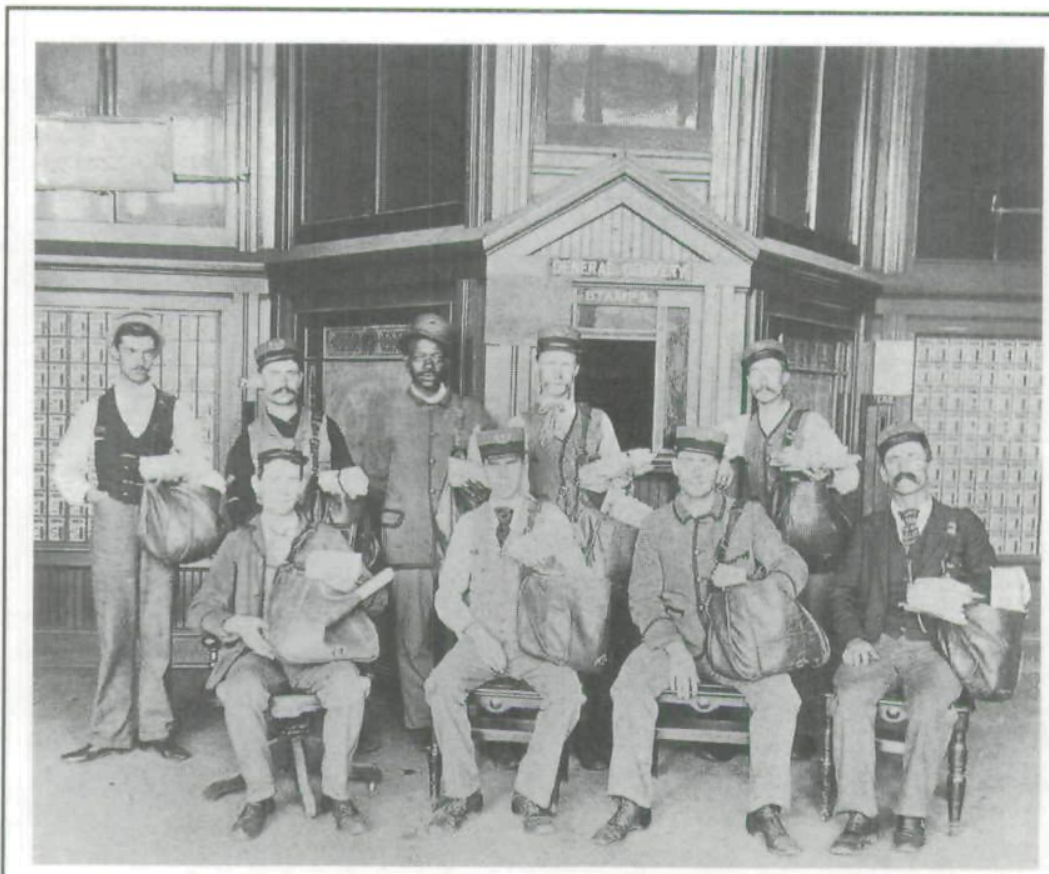

Des Moines postal carriers pose in their mismatched uniforms in 1896. The Post Office Department expected carriers to be "neat and tidy in their dress while officially employed in order that they bring no disgrace upon the service with which they are connected" (quoted in Fuller, RFD, 108-9). Photo courtesy State Historical Society of Iowa, Iowa City (SHSI).

Department executives also standardized work hours. Before 1900, the department did not regulate postal workers' hours, and postmasters were known to leave the management of their offices to their clerks and assistants for days at a time. With the growth of inspection, Washington executives used carrots as well as sticks to establish broad expectations that all postal employees put in a minimum eight-hour workday. When the postmaster at West Union wrote to Washington requesting authority and funding to hire a part-time auxiliary clerk to assist him with a new village delivery program, the department wrote to Fifth District Representative Gilbert N. Haugen stating the conditions that would have to be met in order to obtain additional resources for the West Union office. "The Chief Clerk," the officer wrote to Haugen, "tells me that he is willing to give him four or five hours 


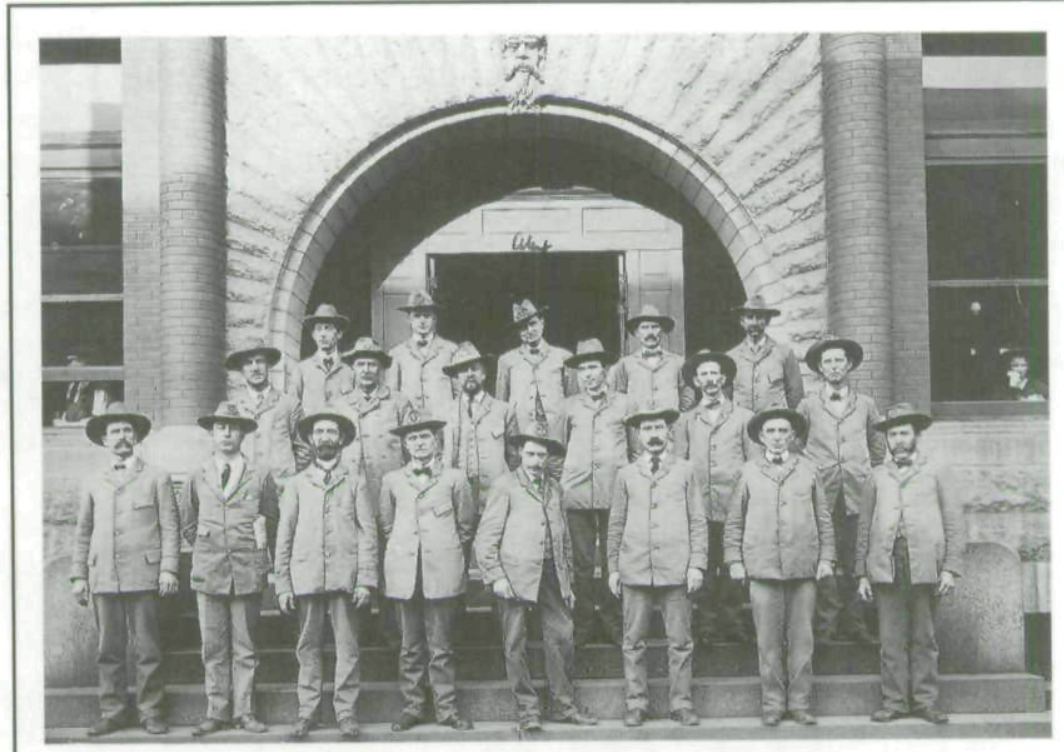

A decade after the photograph on the facing page was taken, Cedar Rapids postal carriers posed in the standardized uniforms. Photo courtesy SHSI.

auxiliary clerk hire, if needed, in addition to himself, assistant and one clerk, which he now has, and also establish village delivery, as the Department does not want P.M.'s to work eleven hours, although they expect them to do a little more than eight." The Chief Clerk's expectation was clear: the job of postmaster was now a "full time occupation. ${ }^{19}$

West Union eventually secured village delivery, but not until other conditions were met. Free delivery service was neither a birthright nor a foregone conclusion for any town at the turn of the century. The postmaster had to meet "civic requirements" defined by the department: a rational mapping and numbering of the town's streets, placing of receptacles for the mail, and so on. As correspondence in the files of Representative Gilbert Haugen shows, no amount of pressure from local elites and legislators could overcome the department's insistence that it would grant free delivery service only where the postmaster

19. Untitled letter (apparently to Haugen) from Department, no date (but probably 1906 and no later than 1910), Haugen Papers, box 99. 
had established an infrastructure for it. The postmaster could officially establish free delivery, but the department would not provide the needed funds and supplies (free delivery envelopes and cards) unless its demands were met. West Union and other offices received additional supplies, additional workers, and additional services only if they could clearly demonstrate the need and the capacity to postal headquarters. What is more, the inspectors' report allowed the department to closely track postmasters' compliance with their demands. Cases such as West Union illustrated the new ways Washington administrators and department inspectors used their power after 1900.

CENTRALIZATION AND STANDARDIZATION were important developments in their own right, but they had an instrumental purpose as well: reducing operating costs and improving the department's bottom line. In part because information about city post offices was so elusive in the nineteenth century, the Post Office began in 1896 to track their procedures in a multiyear survey. The survey traced costs and revenues, the population served and square miles covered in the delivery program, the number of letter boxes, the number of deliveries and collections per week, expenditures for stock, and the average yearly hours worked by postal carriers. The very execution of the survey, as well as the richness of its data, evince the growing inclination of Washington officials to scrutinize local operations. ${ }^{20}$

Department reformers in Washington were most interested in service costs. Without cost reductions, postal officials knew that the system's deficit would continue to represent an insurmountable obstacle to their policy designs. Even more significantly, costs represented the core conflict in the turn-of-the-century Post Office: central control versus local autonomy. When delivery costs rose steadily, as during the free delivery expansions of the 1880 s, autonomy flourished. Higher costs, as a percentage of business volume, meant free spending patterns made possible by the allegiance of postmasters to local elites and Congress.

20. Data from the department's survey reside in the National Archives, and include all post offices of the first and second class in Iowa, or 36 offices during the period 1896-1910. 
FIGURE 2

Cost Reduction in Iowa Post Offices, 1896-1910

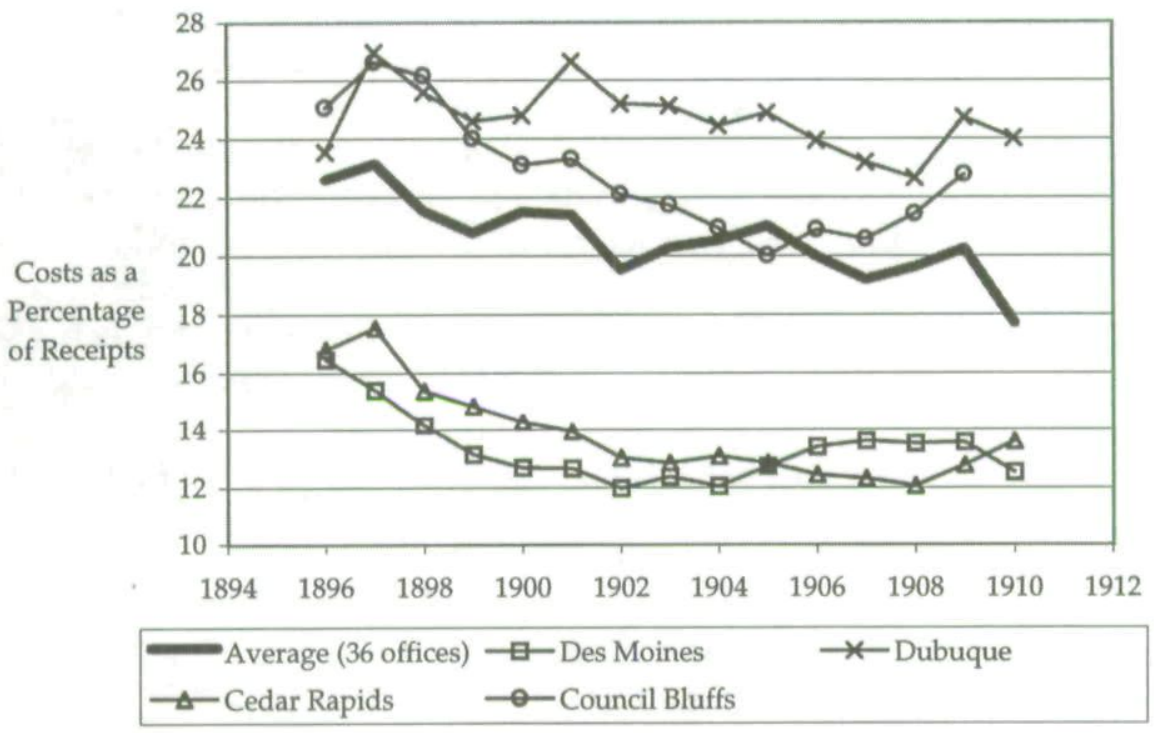

The cost of free delivery declined steadily in larger Iowa post offices at the turn of the century (see fig. 2). On average, delivery costs as a percentage of revenues dropped from 23 percent in 1896 to 19 percent in 1910, a 21 percent improvement. The low cost margins might suggest a surplus, but the department's office statistics hid general system costs. Cross-country transport required enormous payments to railroad companies as well as maintenance of an elaborate network of railway service lines, stagecoaches, and administrative offices, none of which earned revenue but all of which were crucial to the free delivery system. Nonetheless, Iowa post offices returned four cents more per dollar to the department in 1910 than in $1896 .^{21}$

21. National postal statistics show that the decline in the postal deficit-from 13.1 percent of revenues in 1897 to 2.3 percent of revenues in 1910 -was almost certainly driven by increased efficiency in city free delivery. The answer surely cannot lie in Rural Free Delivery, which only increased costs after it began in 1896 (though it did not really begin on a large scale until 1902). Although RFD did boost postal revenues, revenue growth cannot account for the department's improved fiscal state after 1896. Real revenue growth during the period of deficit expansion (1883-1896) was 8.6 percent, almost double revenue growth of 4.6 percent when the deficit was shrinking (1897-1910). The key to 
The department's aims were achieved, then, but were other factors at work? Is there evidence, furthermore, to suggest that the expansion of inspectors was a key factor? Although definitive evidence of the "cause" of the decline is impossible to adduce, the department's survey does allow an examination of this question through a statistical lens. The survey includes a number of variables, including local population, the extent of services (such as the square miles covered in the delivery network, as well as the frequency of collections and deliveries). The survey also measured carriers' office time and total time, both of which suggest the ability of local offices to get their workers to put in more hours.

It is also possible to control for political factors by merging census and voting data into the survey. Partisan strategy strongly affected the operations of post offices even after the end of patronage. Even though first- and second-class carriers were "covered in" by 1894, their bosses were not. City postmasters had impressive political leverage at their disposal. They could employ carriers to canvass for the party, press for greater hiring of clerks and carriers during election years, and use the power of contracting to spend more in areas where the party most needed an infusion of pork. Accordingly, the statistical analyses include two important political variables: the percentage of the popular vote for the Republican congressional candidate in the most recent election and the percentage turnout.

Finally, to assess whether the department's inspection efforts were successful, the analyses include aggregates from National Archives data on all inspectors overseeing postal operations in Iowa, including the percentage of inspectors overseeing an office who were promoted from the RMS.

A "regression" analysis of these unique data shows that several variables had a pronounced effect on costs during this period

the department's fiscal health was a robust reduction in spending growth, from a 9.7 percent annual increase over the $1883-1896$ period to only 3.9 percent annually during the $1897-1910$ period. While the department's reduced payments to railroads undoubtedly helped, the largest expenditure declines were in the 75 percent reduction in annual spending increases. See Daniel Roper, "Statistics of the Postal Service from 1862 to 1910," in Postal Policies and Problems (Washington, DC, 1913); also in Burleson Papers, Library of Congress. 
TABLE 2

SUMMARY OF RESULTS FROM REGRESSION ANALYSIS OF FREE DELIVERY COSTS IN 36 IOWA POST OFFICES, 1896-1910

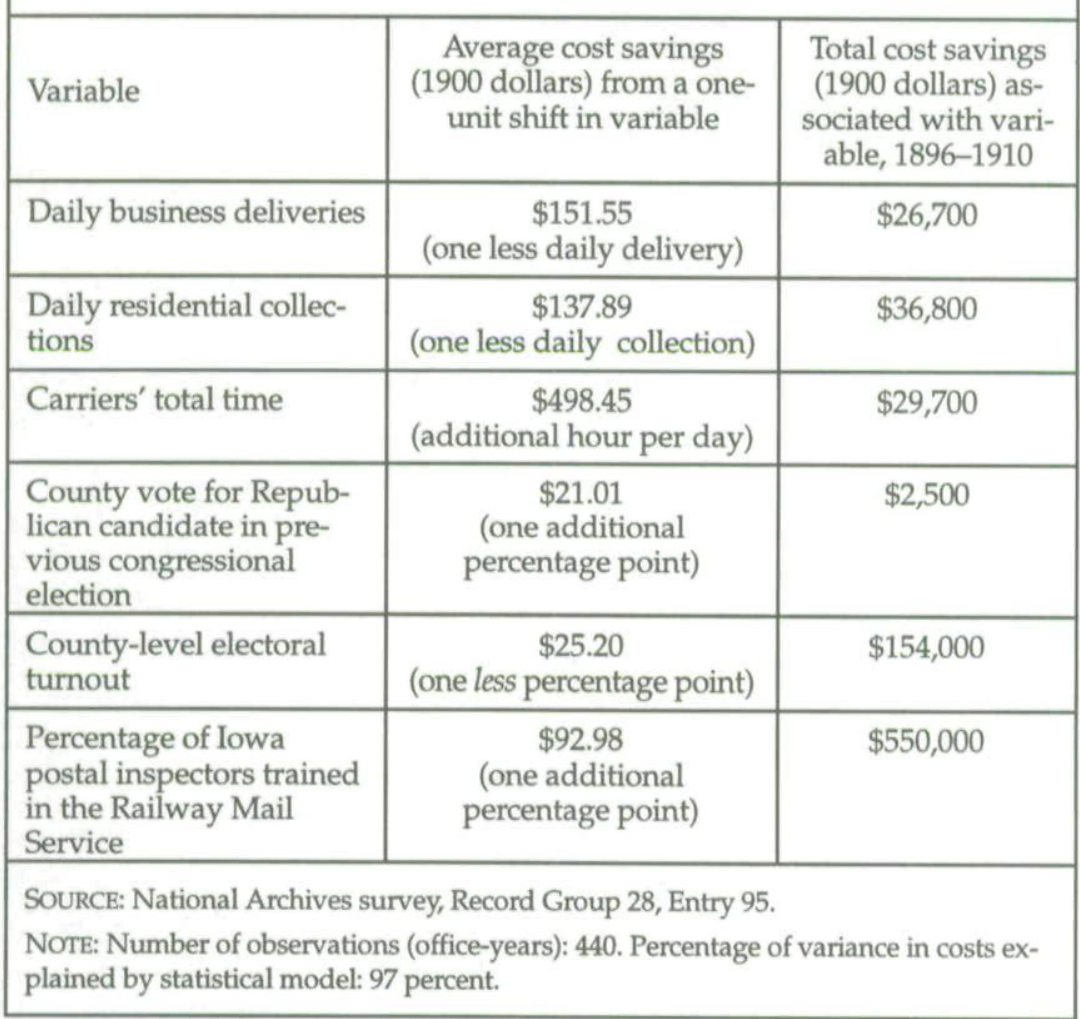

(see table 2). The department's efforts to increase working hours probably contributed to an increase in efficiency. Because postal workers were not paid by hourly wage but were salaried, and because there was no mandatory eight-hour work day, when workers put in more hours, there was less need to hire additional salaried personnel or contract out office functions. Thus, an additional hour of carriers' work over a 10-day period reduced costs by $\$ 500 .^{22}$ The most important factor reducing free delivery costs, however, was the percentage of inspectors overseeing the office who were trained in the RMS. Every percentage-

22. The average carrier worked ten minutes more in 1910 than in 1896 , so this effect is less than it may seem. 
point increase in this index was associated with a drop of $\$ 93$ in annual costs per office. Apparently, then, inspection was having a cost-depressing effect on operations in Iowa and elsewhere. Finally, post offices in Iowa and elsewhere may have spent less money on free delivery as the patronage system waned. As turnout declined after the $1890 \mathrm{~s}$ - from $89.5 \%$ in some Iowa counties in 1896 to $75.6 \%$ by 1910 -politicians' incentive to take advantage of free delivery for partisan purposes also dropped, and so did costs.

Two caveats merit discussion here. First, the period from 1896 to 1910 also witnessed the launching of Rural Free Delivery (RFD). Could RFD have led to these cost reductions? Although RFD sponsored its own efficiencies-particularly the closure of hundreds of fourth-class offices (see below)-the deficit and cost reductions of 1896 to 1910 are little if at all related to the program. Rural Free Delivery did not commence on a large scale in Iowa until 1901 and was not made statutory by Congress until 1902. By that time the department's costs and deficit had been dropping for six years. Moreover, while the RFD service hired its own special agents, they were not unified with the general inspectors' corps until $1905 .^{23}$

Another caveat is interpretive. It would be wrong to attribute the advance of inspection and the reduction in postal spending to the inspectors' initiative alone. Indeed, most of the credit for the cost reduction belongs to the Washington and Chicago officials-Heath, Wanamaker, Chief Inspector M. D. Wheeler, Tyner, Stuart, and others-who sent the inspectors into the field and who drove them to enforce the rules.

23. Many scholars date the origins of the rural free delivery program to 1896, but this attribution is inaccurate for two reasons. First, Postmaster General Wanamaker commenced more than 40 experimental Rural Free Delivery routes in 1891, routes that were discontinued in 1894 for lack of congressional appropriations. Second, the 1896 RFD routes merely reopened the earlier experiments. It was not until the fantastically successful Carroll County (Maryland) experiments of 1899-1900 and a subsequent petition drive (invited by the department) that Rural Free Delivery got off the ground. See Carpenter, "State Building through Organizational Renewal." It is also worth noting that RFD ran at a slight loss for the first several years of its operation, at least on the national level. 
THE ADVANCE OF INSPECTION and the standardization of hours and other practices may have helped the Post Office Department to render new economies from Iowa post offices. Yet the most dramatic change in Iowa postal operations after 1896 was not in the larger first- and second-class post offices, but in the fourth-class offices-small offices serving rural areas. Iowa was home to many of the earliest experimental services in Rural Free Delivery (RFD), the legendary program that promised to bring mail directly to farmers. The legacy of RFD was not simply a new service. Rural Free Delivery was also an instrument by which the postal reform wing attempted to reduce the numbers and the autonomy of fourth-class postmasters. That effort, the evidence from Iowa suggests, was far more successful than has been supposed.

Before 1900, farmers traveled miles, often a full day's travel, to retrieve their mail. In 1891, Postmaster General Wanamaker proposed a radical expansion of free delivery service to small towns. Congress harbored doubts about the fiscal promise of the program, but when the department showed repeated fiscal and administrative success in its RFD experiments, previously reluctant legislators, under pressure from rural constituents, signed on to the program. With support from agrarian legislators, RFD quickly proliferated throughout the American countryside, reaching more than 30,000 communities by the First World War. ${ }^{24}$

The pace of RFD expansion was particularly rapid in Iowa. Thanks to the influence of Third District Representative David B. Henderson-a member of the House Post Office Committee in the 1890s and later Speaker of the House-Iowa received a large share of the first experimental RFD routes. In Iowa as elsewhere, however, Rural Free Delivery carried a mixed institutional legacy. As Roy Atwood has argued in his study of RFD in southeastern Iowa, farmers greeted rural delivery with enthusiasm at first but quickly realized its "cultural contradictions." The program boosted the promptness and quantity of rural mail and made increased communications possible, but it also brought the products of corporate enterprise to the farm, squeezing out

24. See Fuller, RFD, passim; Fuller, "Rural Free Delivery in Hardin County, Iowa," Annals of Iowa 41 (1973), 1049-72, esp. 1049-54. 
local stores and craftwork enterprises, to say nothing of the weekly town newspaper. ${ }^{25}$

The institutional parameters of Rural Free Delivery left enormous discretion in the hands of the Post Office Department. Its experiments under RFD Superintendent August Machen had evinced a newfound capacity for management. At the same time, Congress was largely unable to either micromanage or procedurally regulate the administrative expansion of the system. Thus, the department assumed control of virtually every aspect of rural operations: the selection and mapping of routes, the recruitment of carriers, and, most critically, the termination of fourth-class post offices. ${ }^{26}$

The organization of the Rural Free Delivery Service consciously reflected the signal traits of the Railway Mail Service. Machen and Perry Heath established a set of eight geographic divisions for the RFD Service, creating regional superintendents as in the RMS. These divisions were responsible for establishing thousands of routes per year. An even more significant reflection of the new postal regime was the RFD's reliance on railwaytrained inspectors. All new routes had to be approved by the department; members of Congress could not simply legislate routes into existence as in the case of private bills or works projects. Because the demand for routes outstripped supply, the department had to choose which communities deserved routes and which did not. Doing so required information on the economic feasibility of routes in communities about which few in Washington had knowledge. Accordingly, department procedures gave the decisive role in this choice process to the RFD special agents, who after 1905 were made regular postal inspectors.

25. Roy Alden Atwood, "Routes of Rural Discontent: Cultural Contradictions of Rural Free Delivery in Southeastern Iowa, 1899-1917," Annals of Iowa 48 (1980), 264-73. Of course, many farmers welcomed the lower prices and broader array of products available through RFD, especially after RFD carriers were officially allowed to transport parcels after 1912 .

26. There were occasional exceptions to the department's authority over Service design. Rural legislators resisted the department's attempts to standardize mailbox specifications. Fuller, RFD, 46-47. Instead, the department was allowed to grant authority to 14 companies to produce mailboxes according to POD specifications, an authority that required companies to include the common imprimatur, "Approved by the Postmaster General." 
The first step in obtaining a new route was a casual application from an individual or postmaster, supported by a petition signed by 150 families on the proposed route. The department then referred the route decision to the Division of the Chief Inspector. The division assigned an inspector to visit the route, map it, report on any existing star routes (where contractors on horseback carried the mail), and recommend for or against establishing a route. Rural agents (or inspectors) had nearly total discretion in route selection and management. If the special agent recommended against a route, it was nearly impossible for a community to obtain one, even where its congressman strongly favored it. Agents also had the authority to alter routes, and if they suggested discontinuance the department almost always followed suit. ${ }^{27}$

At the community level, a triangular flow of information developed among the RFD inspector, the congressional representative and department officials. A rich portrait of the relations among these three actors emerges from the papers of Gilbert N. Haugen, the Republican representative of Iowa's Fifth District in northeast Iowa from 1900 to 1928. The agents assigned to the post offices in Haugen's district were Gilbert Guttersen and George Olson. Guttersen and Olson repeatedly sought Haugen's recommendations and suggestions for the manage-

27. See Preliminary Report of the Joint Commission on the Business Method of the Post Office Department and the Postal Service, Senate Reports, 60th Cong., 1st sess., vol. 4 (2 December 1907-30 May 1908), p. 39. Examples abound of rural agents defying Congress in the belief that they held local power. A case in Georgia is illustrative. Despite objections from Senator Alexander S. Clay to some route changes planned by a Rural Free Delivery agent there, the route alterations nonetheless went through. Clay was concerned that the department was exerting too little control over the agent, who "thinks he is the Post Office Department." The department had granted this authority to its rural agents in part because it was so informationally dependent upon them. As Fuller describes them, "Politicians though many of the rural agents were, one can hardly imagine how the farmers' mail system could have been organized without them. For they were the eyes and ears of the Department as they traveled country roads laying out new routes and checking old ones. They built up a wealth of information about rural delivery that was indispensable to the postal officials in Washington. Regulation after regulation based on the agents' reports and designed to take the kinks out of the service went out from the department, until in a surprisingly short time the farmers were receiving their mail every day on the hour with scarcely a mishap." Fuller, RFD, 45-46. 
ment of Fifth District operations. Both Olson and Guttersen went to lengths to let Haugen offer his opinion before advancing their recommendations to the department. The agents sought Haugen's support for their decisions, knowing it would strengthen their hand in Washington. Guttersen became a close correspondent of Haugen's and an active supporter of the congressman's career. He frequently wrote to Haugen on private stationery, informing him of the latest developments in appointments, position vacancies, RFD routes, and the like. According to department custom, Haugen offered recommendations for the reappointment of postmasters at third-class offices, many of which managed their own RFD networks. When new routes were established, Guttersen asked Haugen for his "wishes" as to which carriers to appoint. When Haugen did not make any recommendations, Guttersen selected "active" and "strong" Republicans. Guttersen even campaigned informally for Haugen in his visits to the Fifth District, reporting that "I made it a point to tell everyone I saw that I had 189 applications from Iowa and that yours were the first ones I took up because you were pushing them." ${ }^{28}$

In addition to Haugen, the agents maintained a broad network of contacts in Iowa. Guttersen communicated frequently with Willard Eaton, chair of the Iowa House Ways and Means Committee and one of the most powerful Republicans in the state. Olson appears to have known a number of bankers in the towns whose routes he had inspected. Like fourth-class postmasters, bankers were central elites in rural locales, for they saw virtually the entire population on a frequent and regular basis. They also commanded prestige as country professionals and rural businessmen. And both Guttersen and Olson met with

28. Guttersen and Olson were based in the Indianapolis office of the Western Division of the Rural Free Delivery Service. See Guttersen to Haugen, 16 June 1900, on stationery of the Merchant's Hotel, Osage, Iowa, June 1900 file, box 120, Haugen Papers. For Guttersen's request for Haugen's backing on a decision to close a small post office and discontinue a star route, see Guttersen to Haugen, 11 July 1900, ibid. On third-class appointments, see C. P. Grandfield (First Assistant Postmaster General) to Haugen, 7 August 1908; and Grandfield to Haugen, 21 August 1908, Calmar file, Haugen Papers. On Guttersen's promotion of Haugen, see Guttersen to Haugen, 2 June 1900, box 120, Haugen Papers. See also Guttersen to Haugen, 9 June and 28 May 1900, ibid. 
numerous farmers along the routes they inspected and knew many other notables in the towns they toured. In other counties special agents were close associates of newspaper editors and Republican county committee officials. ${ }^{29}$

As closely intertwined as the agents were with Haugen and the communities in his district, their relationship consisted not of capture, but of mutual dependence for information and political support. The agents ultimately answered not to Haugen but to their department superiors: James Stuart in Chicago, Chief Inspector M. D. Wheeler, and assistant postmasters general such as Joseph L. Bristow, Peter V. DeGraw, and W. S. Shallenberger. In particular, special agents rejected many of Haugen's requests for the establishment or alteration of routes. In 1900 the towns of Calmar and Ossian in Winneshiek County petitioned for routes. Haugen recommended both routes, as important notables in both towns (including Calmar's banker) had written to him for support. Olson inspected the two routes and wrote to Machen recommending against their establishment, noting that the proposed routes overlapped with a route established from the Decorah post office. The department approved Olson's report, marking the cases "adverse" and closing them. Machen's rules constrained Guttersen as well. The postmaster at Osage complained in 1900 that Guttersen had altered the town's route so as to depart significantly from the one petitioned for. Guttersen wrote with a firm rejection of the town's request for remapping and a warning to cease protest.

29. My evidence here, while indirect, is reliable and consistent with other observations and archival materials. Eaton wrote to Haugen informing the congressman of Guttersen's favorable report on a route application for Orchard, Iowa. See Willard L. Eaton to Haugen, 21 February 1900, box 120, Haugen Papers. Olson filed his report on the Calmar and Ossian cases using the stationery of the National Bank of Decorah. Olson to Machen, 29 September 1900, Haugen Papers. Ole P. Ode, the cashier for the Winneshiek National Bank, knew Haugen well and later served on the Republican Central Committee of Winneshiek County. In a 1907 petition for the reappointment of Decorah postmaster J. J. Marsh, Decorah bank officials, including three cashiers, were the first private officials listed in a petition of more than a thousand names. Decorah file, Haugen Papers. Rural agent John T. Boylan was a coeditor of the Eldora Herald and a friend of Charles Albrook, president of the Hardin County Republican Central Committee. See Fuller, "RFD in Hardin County," 1058. 
Mr. Haugen also kicks about this and wants me to have it changed so as to satisfy you and some other friends he has on that north road, this I cannot do and if you and Mr. Hougen [sic] knew what our orders from the department were you would not ask me to do it, for under the conditions that exist in this case you would not then get a route, for the Department would see as I did that by changing it, Dixie P.O. and star route would be discontinued and that expence saved the department. ${ }^{30}$

The department's unencumbered authority to create and terminate routes allowed it to compel cooperation from Haugen and other legislators. When two letter carriers resigned from the Decorah post office in February 1901, Machen wrote to Haugen and asked that he suggest names for hiring. Haugen was perfectly eager to supply names, but in case he was not, Machen added a powerful incentive clause to the letter: "if a suitable person cannot be secured to serve as rural carrier the route will necessarily have to be abandoned." In 1905, Fourth Assistant Postmaster General Peter V. DeGraw chastised Haugen and other rural congressmen for their tardiness in responding to department requests for names for postmaster appointments. Concerned that the delays in appointments were subjecting the department to "embarrassment and criticism," DeGraw instituted a new system requiring recommendations within 60 days

30. Ole P. Ode, the cashier for the Winneshiek County Bank in Calmar, submitted Calmar's petition. Ode to Haugen, 18 July 1900. Machen acknowledged the petitions in a return letter to Haugen, 10 August 1900. Six weeks later, Olson filed his report on private stationery (see above). Olson to Machen, 29 September 1900. All three letters in Calmar file, RFD Correspondence, Haugen Papers. As an indicator of his status and that of other cashiers, Ode later served on the Republican Central Committee for Winneshiek County (see above). Two decades later, he served as president of Calmar's First State Bank. See Sigvart T. Kittlesby to John H. Bartlett, First Assistant Postmaster General, 23 February 1928, ibid. For the decision on the Calmar and Ossian cases, see Johnson to Haugen, 9 January 1901, ibid. (Department File "Rural-F-118-HAB"). Machen's initials appear at the top right corner of the letter. Two weeks later, the department approved RFD for the Decorah post office, a second-class office. Johnson to Haugen, 22 January 1901 (Department File "S-F-39-FH"). Calmar later became a third-class ("Presidential") office and received RFD. See C. P. Grandfield, First Assistant Postmaster General, to Haugen, 7 August 1908, Calmar file. On the Osage route case, see Guttersen to Postmaster of Osage, 7 July 1900, July 1900 file, RFD Correspondence, Haugen Papers. 
of a request; otherwise the department would exclude congressmen from the selection process. ${ }^{31}$

THE DEPARTMENT employed two criteria-partisanship and literacy-in selecting which communities got routes and which did not. Postal officials used the first criterion informally, the second publicly. Partisanship was a salient factor separating the abundance of routes in northern districts from the dearth of routes in the South. McKinley and Roosevelt Republicans saw immense political advantage in expanding routes to the satisfaction of the rural interior communities that had been essential in the victories of 1896 and 1900. The stark differential was not lost on congressional Democrats. One noticed that Kansas, "as rock-ribbed and everlasting in her republicanism as South Carolina in her democracy," had over a thousand more routes than South Carolina. ${ }^{32}$ In response the department admitted the geographical differential but attributed it to the necessity of placing routes where literacy and readership were high. Yet the force of partisanship is undeniable. In an innovative analysis of the distribution of routes across districts, Samuel Kernell and Michael McDonald show that the department allocated routes so as to strengthen the congressional majority Republicans had won in 1894. Republican districts received more routes than Democratic incumbents did, of course, but the effects depend critically upon the electoral competitiveness of recent races. Republican incumbents in recently acquired districts received more than ten times as many routes as Democratic incumbents in swing districts. ${ }^{33}$

Although scholars have doubted that the department truly cared about literacy in its route allocations, variations in readership were a crucial factor in department decision making. Readership meant consumption, and department officials desperately needed to show profits to convince Congress to fund RFD

31. Machen to Haugen, 21 February 1901, Decorah file, Haugen Papers (Department File "Rural-F-992-O"); DeGraw to Haugen, 7 July 1905, RFD Correspondence, Haugen Papers.

32. Quoted in Fuller, RFD, 64.

33. Samuel Kernell and Michael McDonald, "Congress and America's Political Development: The Transformation of the Post Office from Patronage to Service," American Journal of Political Science 43 (1999), 792-811. 
expansion. Accordingly, special agents such as Olson and Guttersen repeatedly pointed to literacy in their investigations of proposed routes. Olson denied Haugen's request for RFD at Calmar because the proposed route would have left "two-thirds of the most intelligent Citizens and patrons unserved." Olson then approved service at Decorah because its post office was "one of the very best in this part of the state, doing a very large business for its size." Rural citizens knew of the department's preferences for high literacy rates and incorporated them into their petitions. Hardin County residents advertised their "distinguished honor of having the smallest per cent of illiteracy of any county in the nation. It is the exception to find a home without a newspaper and other valuable reading matter." Because areas where income, readership, and literacy were high were also areas that strongly supported Roosevelt Republicans, the department's efforts to maximize RFD profitability also served political ends. ${ }^{34}$

From an institutional perspective, of course, the central and most neglected story of RFD concerns not route allocation but the displacement of fourth-class post offices. With administrative control of RFD after 1900, Machen proceeded to eliminate the country postmaster. He secured Postmaster General Charles Emory Smith's consent to issue a departmental regulation in 1901 requiring the closure of at least one fourth-class post office in each community served by a new route. Aiming for efficiency

34. Olson to Machen, 29 September 1900, Calmar file, RFD Correspondence, Haugen Papers; Fuller, "Rural Free Delivery in Hardin County," 1054. Kernell and McDonald doubt the department's literacy-based rationales, but for Washington officials who closely tracked revenue statistics, the relationship between literacy and revenues was an ineluctable fact. City free delivery revenues provided the best indication; revenues were sharply higher where patrons were more literate. Revenues also increased with readership and income, that is, precisely in those northern states where Republicans dominated after 1896. From 1896 to 1910, first- and second-class offices in Iowa (where the illiteracy rate was 2.1 percent) had average per capita receipts of $\$ 3.37$, whereas offices in Texas (where the illiteracy rate was 14.25 percent) had per capita receipts of $\$ 2.67$ over the same period. A regression analysis of free delivery receipts in Pennsylvania, Iowa, and Texas from 1896 through 1910 revealed that postal revenues in first- and second-class offices were positively related to the county Republican vote $(t$-ratio $=22.58)$ and negatively related to the county illiteracy rate $(t$-ratio $=-6.134)$ (the minimum $t$-ratio for a finding of statistical significance is an absolute value of 1.96). 
and the undermining of nineteenth-century tradition, Machen's officials targeted long-entrenched postmasters in small towns. In some respects, the department's choices amounted to outright age discrimination. In December 1908 First Assistant Postmaster General C. P. Grandfield eliminated the post office at Hustad because "the postmaster, who is about eighty years of age, is unable to look after the office. ${ }^{\prime \prime 6}$

The postmasters fought back with passion and tact. Even where new routes did not snuff out their offices, RFD threatened to bypass their role in mail distribution, reducing the number of through customers for their general supply stores and limiting their influence in the local community. The postmasters joined with star route carriers in petitioning members of Congress to pressure the department to delay or obstruct the introduction of Rural Free Delivery in their localities. They also befriended the rural agents, persuading them to draw routes that would originate with or intersect their offices, to preserve their role in the new scheme of distribution. ${ }^{37}$

Wayne Fuller, the most thorough historian of the Rural Free Delivery system, has argued that RFD resulted in less uniformity and efficiency than national postal officials would have liked. In his study of RFD operations in Hardin County, Iowa, Fuller claims that Machen's efforts to dispose of fourth-class post offices were largely unsuccessful. Few post offices were eliminated, Fuller argues, due largely to local capture of the special agents and the resistance of fourth-class postmasters. The postmasters "cajoled and argued and threatened," putting members of Congress in the unhappy predicament of having to choose between routes for their constituents and the livelihoods of powerful local elites. Fuller concludes that the congressmen

35. For discussion of Smith's order, see his Annual Report, 1901, 11-12. Also Fuller, "Rural Free Delivery in Hardin County," 1061. The department also asked Haugen for information and gave him the chance to object.

36. Grandfield to Haugen, 22 December 1908, Haugen Papers.

37. Carroll County, Maryland, for instance, had 94 fourth-class postmasters and dozens of star-route (horseback) mail carriers. They "vigorously denounced" Machen's experiment and "succeeded in creating in some quarters a strong but temporary opposition to the service." See Machen's report, "Rural Free Delivery in Carroll County, MD," 4;Fuller, RFD, 51-52, $100 \mathrm{ff}$. 
were usually able to secure both. In Hardin County, he found that only 3 of 42 - or less than 10 percent-of fourth-class post offices were terminated after the introduction of RFD. ${ }^{38}$

It is evident, however, that the department's efforts were far more successful elsewhere in Iowa. Roy Atwood intimates as much in his study of RFD's effects on communities in southeastern Iowa. Atwood reports "numerous accounts of post office closures in the small communities" in that area, as many as 207 fourth-class closures in 1909 alone. ${ }^{39}$ Haugen's papers allow even more precise estimates, as he kept a personal notebook of all of the post offices in his district. Haugen's notes report every change of postmaster, the population served by the office, its services (such as money orders) and date and cause of any office termination. Analyses of a six-county sample of these records show that the rate of termination for fourth-class post offices appears far higher than Fuller's study of Hardin County would suggest. Of 132 post offices sampled from Haugen's district, 49 (or 37 percent) closed by 1908-a rate of termination five times higher than Fuller observed in Hardin County. A separate statistical analysis shows that fourth-class post offices died more quickly after 1901 precisely where their postmasters had longer tenure.

The patterns of Haugen's district were replicated nationwide. In the twelve years following Machen's report in 1900, the department eliminated almost 20,000 fourth-class post offices. Nationally, the total number of post offices fell from 76,945 in 1901 to 58,729 in 1912 . The immense popularity of Rural Free Delivery made this process easier, of course. So too did the Republican leanings of many rural carriers. Members of Congress knew that in eliminating offices to make way for RFD, they were trading one set of Republicans for another. The carriers' civil service test was commonly regarded as an easy one, so the Republican leanings of many special agents gave the RFD the appearance of a patronage system in the clothing of Progressive efficiency. ${ }^{40}$

38. Fuller, "Rural Free Delivery in Hardin County," 1049-72.

39. Atwood, "Routes of Rural Discontent," 269 and fn14.

40. See Kernell and McDonald, "Congress and America's Political Development," fig. 1. Congressional Republicans were keenly aware of the immense 


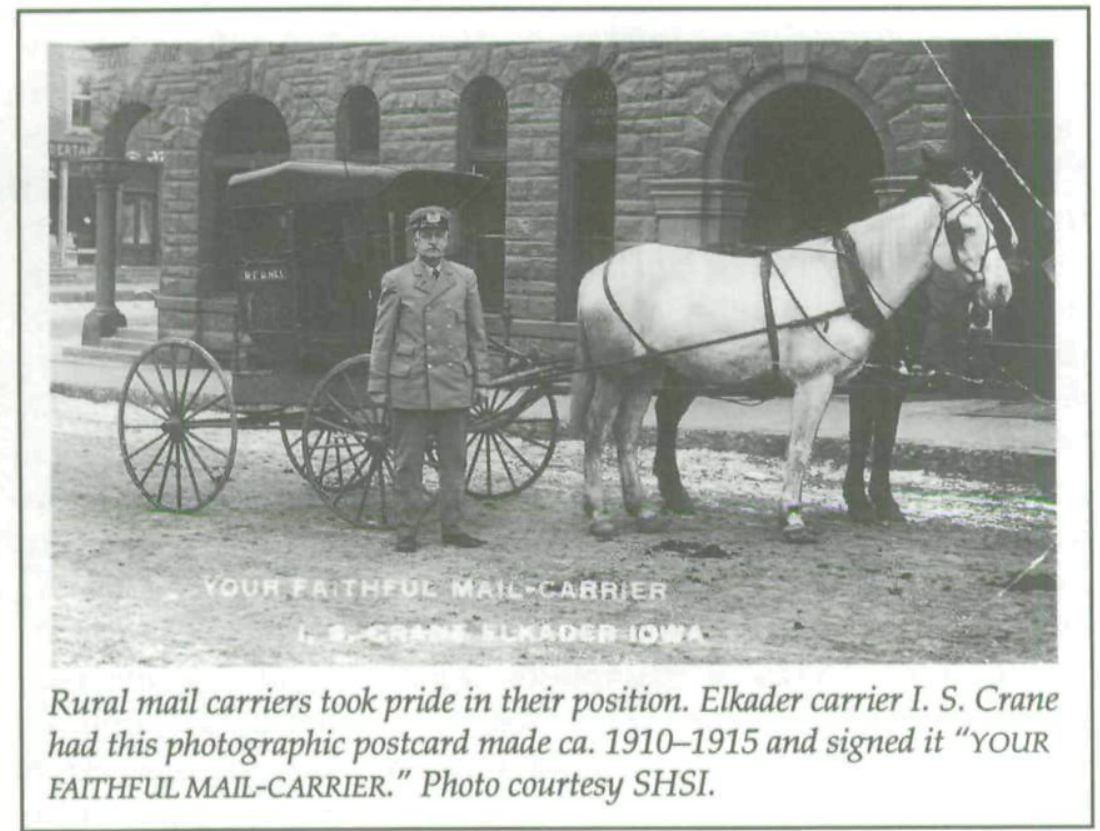

Yet the popularity of RFD only goes so far to explain why congressional Republicans were willing to sacrifice the fourthclass postmaster. Kernell and McDonald argue that "nearly everybody" understood the necessity of office closure as RFD expanded, but they offer no evidence. With the department's deficit declining and Rural Free Delivery running a solid surplus by 1905, posing no threat to the department's fiscal discipline, it is not clear why congressional Republicans could not have stemmed the bleeding of their old (and continued) friends. Moreover, the opposition of the postmasters and star route contractors was intense. Why did the fourth-class office die such a quick death? No adequate explanation can ignore the entrenched pattern of deference that prevailed between the House Post Office Committee and the Post Office Department.

political value of the rural carriers. As W. B. C. Brown, Republican congressional nominee, wrote in a letter to Postmaster General Charles Emory Smith: "We ask that the Rural Mail Carriers, who will daily penetrate every part of this country, may be Republicans, each and every one." Brown and others to Smith, 2 November 1901, County Rural Delivery Records, Jackson County, Missouri, NA; quoted in Fuller, RFD, 59. 
While the committee constrained office elimination, its members were more interested in which offices got axed than in how many. Machen's officials could terminate more offices than efficiency counseled simply because they were better informed and broadly trusted. And when a member such as Haugen opposed elimination of a particular post office, the department often acquiesced to his interests by hiring more carriers to cover the routes of the eliminated office. Carriers were less costly than offices, yet were still politically valuable. Most important, however, was Congress's growing institutional trust in the department to run the system efficiently, a confidence seated firmly in the House committee and its leaders Eugene Loud, John Wadsworth, and John Weeks. The department had invented RFD. It had issued and secured local compliance with scores of regulations, rendering the system efficient. And it had done all this without upsetting the Republican majorities of 1896 and 1900. In addition, the long-criticized postal deficit had begun, for the first time in a generation, to disappear. For Congress to acquiesce to Machen's and other officials' aim of winnowing the ranks of fourth-class postmasters-to grant them lasting and relatively unencumbered hold over the rural delivery system-was in some respects a reward for service rendered.

WITH THE STANDARDIZATION of city operations and the overhaul of rural mail operations, a new postal system emerged in Iowa after the turn of the century. It was characterized less by patronage than by policy, less by local autonomy than by increasing regulation from Washington. Other historians-Wayne Fuller and Roy Atwood, among them-have documented the cultural, political, and economic implications of these changes. Yet the centralization campaign in Iowa post offices also reveals a different, perhaps more troubling legacy: the eclipse of women's managerial roles in postal administration.

For all of its obvious faults, the old regime of patronage had some peculiar and little noticed benefits for the families of Iowa postmasters and for women. To begin with, in smaller (secondto fourth-class) post offices, patronage often meant nepotism. The postmaster (usually male) often hired his wife as assistant 
postmaster and his sons, daughters, cousins, nieces, and nephews as clerks. Moreover, because the postmaster's job was not seen as a full-time office occupation, the postmaster frequently left management of the office to his family, most often his wife. In Indianola, Anna Dowell was assistant postmaster to her husband, E. B. Dowell. In Emmetsburg, Alizanah Appelman was assistant postmaster to Frank S. Appelman, and Lena A. Gusland continued the local tradition of women's management by taking over for Alizanah after the latter resigned in August 1900. In this respect, nineteenth-century small-town post offices were literally family operations. Some women, such as Susan C. Carpenter of Fort Dodge (wife of former governor Cyrus Clay Carpenter, who had served as postmaster at Fort Dodge from 1889 to 1893) even held the postmaster position itself. More generally, women occupied many of the more elevated administrative roles in post offices before 1900, including superintendent of money orders (Harriet J. Maish of Des Moines), money order clerk (Ruberta and Loretta Brown of Des Moines), and registry clerk (Mary E. Harrison of Davenport). Money order clerks and registry clerks, while "clerks" in the literal sense, had far more meaningful jobs than "stampers" and "general utility clerks." Moreover, the greater breadth of their responsibilities was reflected in higher pay. Money order clerks earned $\$ 700$ annually, compared to $\$ 400$ or $\$ 500$ for stampers and general utility clerks. ${ }^{41}$

With increasing departmental control of hiring practices after 1900, the managerial and administrative presence of women in Iowa post offices began to give way to mundane clerkships. In personnel rosters for first-, second-, and third-class post offices in Iowa from the National Archives, it is possible to identify 68 women who worked at some time from 1890 to 1905 . Of these women, 37 were hired before 1900 and 31 were hired from

41. The information on women in post office employment is contained in employee and salary registers for first-, second-, and third-class offices in the National Archives. See RG 28 (Post Office Department), E 78 (Salary Rosters for Clerks in First-, Second- and Third-Class Offices), which also includes information on office superintendents, assistant postmasters, and postmasters. I have collected and maintain a full spreadsheet archive of all employees in the rosters for 1890 to 1905 in Iowa, Pennsylvania, and Texas. 


\begin{tabular}{|c|c|c|}
\hline $\begin{array}{r}\text { TABLF } \\
\text { THE TRANSFORMATION } \\
\text { IN IOWA POST OFFICES BE }\end{array}$ & $\begin{array}{l}3 \\
\text { F WOMEN'S RO } \\
\text { ORE AND AFTER }\end{array}$ & 900 \\
\hline Position (salary) & $\begin{array}{l}\text { Number of } \\
\text { women hired } \\
\text { to position } \\
\text { before } 1900\end{array}$ & $\begin{array}{l}\text { Number of } \\
\text { women hired } \\
\text { to position } \\
\text { after } 1900\end{array}$ \\
\hline Postmaster $(\$ 1200-\$ 1400)$ & 1 & 0 \\
\hline Assistant Postmaster $(\$ 1000)$ & $0^{a}$ & 5 \\
\hline $\begin{array}{l}\text { Superintendent of Money Orders } \\
(\$ 800-\$ 1000)\end{array}$ & 1 & 0 \\
\hline Money Order Clerk $(\$ 700-\$ 800)$ & 7 & 2 \\
\hline Registry Clerk $(\$ 600-\$ 700)$ & 3 & 1 \\
\hline Stampers $(\$ 300-\$ 400)$ & $13^{\mathrm{b}}$ & 21 \\
\hline $\begin{array}{l}\text { Median women's salary upon hire } \\
\text { (nominal dollars) }\end{array}$ & $\$ 700$ & $\$ 500$ \\
\hline Percentage of women hired as stampers & $35 \%$ & $68 \%$ \\
\hline Number of women hired & 37 & 31 \\
\hline \multicolumn{3}{|c|}{$\begin{array}{l}\text { SOURCE: National Archives personnel records of first-, second-, and third-class post } \\
\text { offices, 1890-1905, RG 28, E 78. }\end{array}$} \\
\hline \multicolumn{3}{|c|}{$\begin{array}{l}\text { "Although no women were appointed as assistant postmaster before 1900, three of } \\
\text { the women appointed were later promoted to assistant postmaster. }\end{array}$} \\
\hline \multicolumn{3}{|c|}{ beven of the thirteen stampers before 1900 were hired in 1898 and 1899.} \\
\hline \multicolumn{3}{|c|}{$\begin{array}{l}\text { 'The salary comparisons use nominal dollars. If real dollars are used, the statistics } \\
\text { show an even greater decline in women's salaries after } 1900 .\end{array}$} \\
\hline
\end{tabular}

1900 to 1905 . The 37 hired before 1900 illustrate the diversity of positions women occupied in nineteenth-century Iowa. Four women served as chief clerk of their post offices, seven as money order clerk, one as postmaster, and only thirteen as "stampers," the lowest-ranking clerical job of the post office. Of the thirteen stampers, seven were hired in 1898 and 1899.

The Post Office Department's standardization and centralization movement brought lower-rank positions for Iowa women (see table 3). Women were far less likely after 1900 than before to be hired as money order clerks or registry clerks. They were more likely to be appointed as assistant postmasters, as it turns out, but several of those women soon resigned or were terminated 


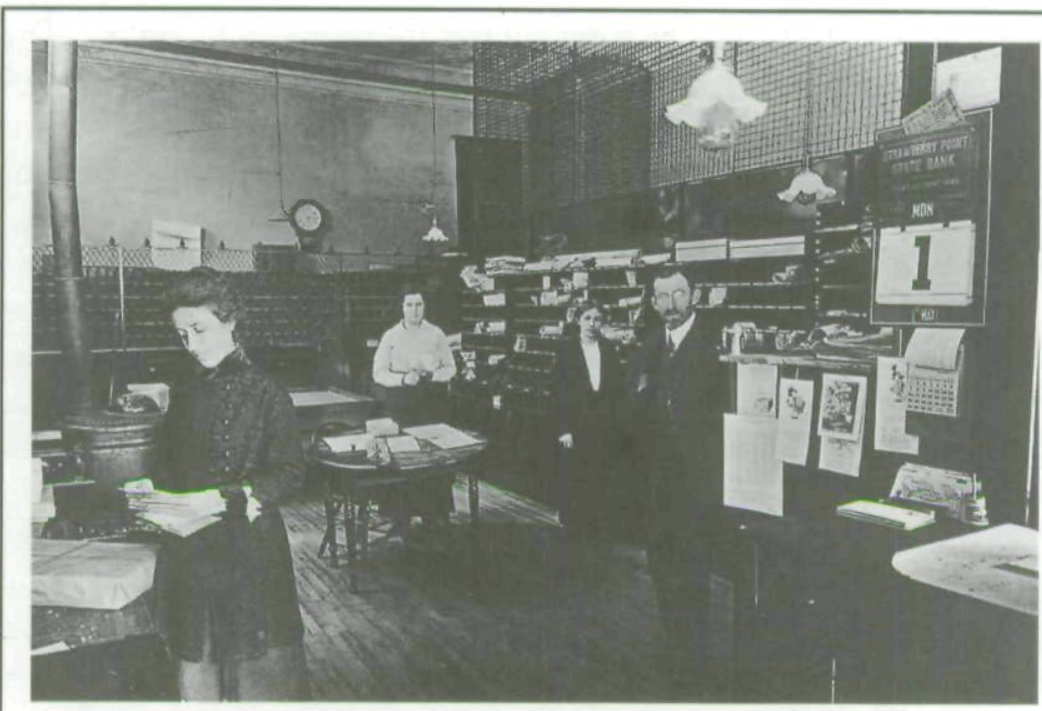

Women clerks sort mail under male supervision in the Strawberry Point post office, 1911. Photo courtesy SHSI.

and, in either case, were replaced by men. The most dramatic transformation of women's employment in Iowa post offices after 1900 came in the standard job they occupied. Of the 37 women in this sample of Iowa offices before 1900, only 13 were hired as stampers, the lowest rung in the administrative hierarchy. By contrast, over two-thirds of all women hired from 1900 to 1905 in those offices, or 21 of 31, were hired as stampers. The effect of moving women into mundane clerical work also affected their livelihoods. Even without taking inflation into account, the median salary for women hired in Iowa post offices after 1900 dropped by two hundred dollars.

While the decline of women in managerial positions is stark, it is not clear why women were hired in greater numbers as stampers. As a broader current within Progressive society, of course, the trend toward the "clericalization" of women's work has been well documented. The expansion of managerial work in the turn-of-century corporate workplace linked masculinity with discretion- and power-laden jobs. As the division of labor in the American economy widened, and as Victorian social mores took greater hold, a clerical position was increasingly seen as "a 
position that God has not particularly assigned to men." The American economy needed women as workers, but American culture relegated them to positions without meaningful authority. In this respect, the gender trends in Iowa post offices echo a race-based division of labor in other areas of the Post Office Department, especially the Railway Mail Service, where white clerks staffed the moving mail trains while black clerks worked in less glorious "terminal RPO" jobs in train stations. In the early twentieth century postal "machine," "manly" labor combined mental endeavor and physical exertion, and often authority as well. Women were hired into clerical positions because such posts were increasingly seen as "natural" or "predestined" for them, and as unfitting for men (especially white men). ${ }^{42}$

When women did become postmasters, it could stir controversy. Jessie Teeling succeeded her father E. H. Teeling as postmaster of Charles City's second-class post office in Floyd County in 1897. Shortly thereafter, several citizens began to make noise, arguing that, as a woman, Teeling was unfit for office and served only because of her father's good name. L. H. Henry, a prominent local businessman and Republican stalwart, campaigned vigorously to replace Teeling at the end of her term in 1903. It appears that Henry actually began his campaign in 1899, fully four years before Teeling's term ended. In July 1902, Henry followed up on earlier correspondence with Gilbert Haugen, Charles City's representative, and J. J. Howley, First Assistant Postmaster General, complaining that Teeling was not delivering mail to his supporter J. Butterfield. The department investigated and found "satisfactory service." A diverse group of local notables rallied in support of Teeling. They circulated a petition, sent it to Haugen and the department, and wrote numerous letters. Charles City attorney W. S. Prouty reminded Haugen of

42. Carole Srole, "Feminization of Clerical Work." Because of expanding labor demand, women did not move from the workplace to lives of pure domesticity. See also Kenneth Lipartito, "When Women Were Switches: Technology, Work, and Gender in the Telephone Industry, 1890-1920," American Historical Review 99 (1994), 1075-1111; Carpenter, "The Corporate Metaphor and Executive Department Centralization in the United States." Throughout this period, women were hired as carriers only if they were widows of U.S. soldiers or wives of disabled veterans. 
the "growth of the business done at the [Charles City] office, the accuracy and dispatch with which business is done and the obliging manners of Miss Teeling and her employees under her administration." Carl Merckel stated that Teeling had "kept the P.O. here in a good, straight Business like manner" and reported from his vantage as a "Mainstreet" businessman that "less mistakes have been made since she [Teeling] has control of the P. O. than by any incumbent gone before." Some of the letters for Teeling were patronizing, as J. H. Parker wrote that his "object" was "to shield a young girl from the attacks of a scheming politician who is working for selfish ends. ${ }^{\prime \prime 3}$

Henry's proponents quickly fought back. H. J. Durkee's letter to Haugen in January 1903 illustrates the gendered rhetoric that Henry's followers used.

\section{My Dear Haugen:-}

As the crisis is approaching in the Charles City post office I want to say a word or two in favor of the RIGHT MAN, who by all laws of political warfare is justly entitled to the office. The hue and cry raised ... for a second term for the woman is nothing more nor less than an effort to defeat L. H. Henry by enlisting the sympathy of weak minded patrons of the office for the woman. ${ }^{44}$

Later that year, Teeling was replaced by the very man who had sought to evict her from office: L. H. Henry. ${ }^{45}$

Statistics clearly document the gendered consequences of postal reform in Iowa's first-, second-, and third-class post offices, and Teeling's experience illustrates the gender dynamics operating in communities with post offices of that size. For communities with fourth-class post offices, however, the gender picture is more complicated. Women continued to serve as fourth-class postmasters, and it appears that the centralization campaign did not materially reduce their hiring. From Elizabeth

43. Prouty to Haugen, 21 December 1900; Merckel to unknown recipient [possibly Howley], 20 October 1902; J. H. Parker (Northwood, IA) to Haugen, 28 July 1902, all in Charles City file, Haugen Papers.

44. H. J. Durkee (Nashua, IA) to Haugen, 29 January 1903, Haugen Papers, Charles City file.

45. Appointment information from Haugen Post Office Scrapbook, Haugen Papers. Gilbert Haugen's role in the replacement is not clear. 
Crowe, appointed "postmistress" at Fayette County's Clermont office in June 1911, to Emma Nicolay, who managed the Postville office in Allamakee County from 1915 into the 1920s, women commonly led fourth-class offices after 1900, more than fifty women in Haugen's district alone.

Yet the demise of the fourth-class office illustrates all too clearly how large-scale dynamics of postal change were reducing opportunities for women. No matter how many small communities favored women as officeholders, the elimination of offices in those communities was being pressed by "efficiency"-minded postal officials in Washington. Furthermore, the rural carriers who replaced fourth-class postmasters were almost uniformly male; in Cedar Rapids, not a single woman served as city or rural free delivery carrier in 1911.

What about postal centralization drove women into mundane clerical positions? One possible explanation lies in the conservative Victorian morality of the leaders of the postal reform movement in Washington. Anthony Comstock's traditionalist (from a contemporary vantage, even sexist) views on women's roles are now well known. It is also worth remembering that the postal reform wing grew out of the Railway Mail Service, which at the turn of the century laid claim to a highly insular and fraternal identity. The railway mail clerks were all male and looked down on post office work, and the service exhibited a stark racial segregation. In short, the growth of a Progressive "efficiency" movement in government administration did not include gender or racial equality as core ideals. ${ }^{46}$

IN THE DEVELOPMENT of American political institutions, postal centralization was important less for its new instrumental efficiencies than for increasing the presence of the national state in citizens' lives. After 1900, Iowa post offices of every class began to look more and more alike. They shared two daily residential deliveries, rural free delivery service, and

46. On Comstock, see Nicola Beisel, Imperiled Innocents: Anthony Comstock and Family Reproduction in Victorian America (Princeton, NJ: 1997). On the insular racial identity of the Railway Mail Service, and its connection to metaphors used by RMS workers, see Carpenter, "The Corporate Metaphor and Executive Department Centralization," 191-94. 
reduced costs. They received more and more visits from inspectors. They witnessed fewer women in positions of discretion and authority. All of those transformations depended on the designs of postal officials in Washington and the increasing trust they commanded from the House and Senate Post Office Committees who allowed discretionary administration over the postal system. For better or worse, postal centralization made the Post Office Department a more integrated projection of the American "state." 
Copyright of Annals of Iowa is the property of State of Iowa, by \& through the State Historical Society of Iowa and its content may not be copied or emailed to multiple sites or posted to a listserv without the copyright holder's express written permission. However, users may print, download, or email articles for individual use. 